\title{
An Analysis on Ibn Khaldun's Methodology in Social Change
}

\author{
Harliana Halim ${ }^{1}$, Kamaruzaman Yusoff ${ }^{2},{\text { Aminuddin } \text { Basir }^{3} \text {, Rosman Md. Yusoff }}^{4}$, Siti Sarawati Johar ${ }^{5}$, Mohd \\ Hisyam Abdul Rahim ${ }^{6}$, Hani Suraya Aziz ${ }^{7}$, Abdul Shakor Borham ${ }^{8}$ \\ ${ }^{1}$ Centre for General Studies and Co-curricular, Universiti Tun Hussein Onn Malaysia \\ ${ }^{2}$ Fakulti Tamadun Islam, Universiti Teknologi Malaysia \\ ${ }^{4}$ Pusat Citra, Universiti Kebangsaan Malaysia \\ ${ }_{4,5,6,8}$ Centre for General Studies and Co-curricular, Universiti Tun Hussein Onn Malaysia \\ ${ }^{6}$ Centre for Language Studies, Universiti Tun Hussein Onn Malaysia \\ *Corresponding author E-mail: harliana@uthm.edu.my
}

\begin{abstract}
In the realms of historical sociology, Ibn Khaldun is a name that strikes absolute familiarity among experts. However, the discussions expressed in historical sociology debates do not specify how Ibn Khaldun's ideas and thoughts were actually focusing on social changes that occur in a society. Hence, the discussion of this article will analyse the approaches and methodologies applied by Ibn Khaldun in analysing the social changes that took place during his lifetime and prior to it, as recorded in Muqaddimah Ibn Khaldun. This paper uses a historical descriptive qualitative research approach. Facts were analysed using a text analysis approach in understanding Ibn Khaldun's methodology on social change and Muqaddimah Ibn Khaldun, assisted by induction and deduction approaches. As a result, the researcher found that Ibn Khaldun applied a diversity of approaches in discussing social changes which encapsulate humanitarian, historical philosophy, inquiry, logic and metaphysical, critical and critique, realistic, inductive and deductive, comparative, observational and participatory approaches in studying social changes issues. In addition, he also applied a combination of critical approaches and contextual knowledge, as well as thematic and descriptive approaches in writing. This proves how significant the social changes issues were to Ibn Khaldun, thus they needed to be monitored and managed wisely.
\end{abstract}

Keywords: Ibn Khaldūn; Methodology; Social Change

\section{1 .Introduction}

Barry Gower in his book Scientific Method states, "We need to know something about scientific method in order to understand the production of new knowledge" (1997). In the history of the birth of new sciences, the newly created sciences also introduce new scientific methodologies in terms of research approaches or in terms of writing methods. Based on the researcher's analysis, there is a truth to this statement. The study of Ibn Khaldun's thoughts on social change reveals the varied approaches used by him to convey the writing of social change in Muqaddimah Ibn Khaldun.

He even stated in his book that the creation of a new methodology which he thought was more systematic and innovative;

I followed an unusual method of arrangement and division into chapters. From the various possibilities, I chose a remarkable and original method. In the work, I commented on civilization, on urbanization, and on the essential characteristics of human social organization, in a way that explains to the reader how and why things are as they are, and shows him how the men who constituted a dynasty first came upon the historical scene. As a result, he will wash his hands of any blind trust in tradition. He will become aware of the conditions of periods and races that were before his time and that will be after it (1).

Based on the above quote, it is clear that the diversity of the methodology was used by Ibn Khaldun in analysing social change. The diversity of the methodology includes the following approaches; humanitarian science, historical philosophy, inquiry, logic and metaphysical, critical and critique, realistic, inductive and deductive, comparative, observational and participation in studying issues of social change. Ibn Khaldun occasionally incorporated the diversity of these approaches to obtain comprehensive and realistic data in his writings, such as the combination of critical approaches and contextual knowledge, which he gained experience and extensive reading. In addition to the way he presented his writings on social change, Ibn Khaldun also applied both thematic and descriptive approaches.

\section{Ibn Khaldūn Methodology to Discuss So- cial Changes}

Ibn Khaldun's first approach in discussing social change was to use the thinking framework of humanitarian science. Humanitarian science is a study and interpretation of human-related experiences, activities, structures and artifacts (2). Humanitarian science studies are carried out to develop knowledge and to educate people of their existence, relationships with other systems and species as well as the development of artifacts in order to understand people and thoughts. It is also a study of the human phenomena and the human experience throughout history and time in nature. This study requires assessment and interpretation from historical human experience and the analysis human activity to understand the human phenomena and outline the development of proper human evolution. Humanitarian science is an objective and accurate criticism of human existence and how it relates to reality. 
Ibn Khaldun studies human beings as the basic element of all lives on earth. Therefore, the humanitarian science approach is the most appropriate approach in describing the social changes associated with human beings. The selection of human subjects by Ibn Khaldun was in line with the Islamic philosophy, in which human beings as caliphs are responsible for managing himself, his family, his community, his nation and his environment with full accountability. This is done to meet the human needs and it is part of human nature, where men are weak servants and dependant to God.

The approach to humanitarian science also includes social science and moral science which refers to studies conducted on human life and daily activities. These sciences are related to the study of phenomena occurring through the authenticity of experience and observation or observation using sensory and psychology (3). Furthermore, the humanitarian science approach is not limited to studies on humanity modes social science and humanity, but also includes history, sociology, anthropology and economics.

As a historian of philosophy, Ibn Khaldun was known to apply philosophical approaches in understanding the wisdom behind the historical events. His ability to apply wisdom in understanding the historical patterns of social change was deemed remarkable. This was due to the fact that he was successful in connecting history with philosophy to show how history provides inspirational and intuitive powers to philosophy, while philosophy provides logical strength to history. With a critical and logic mind, a historian will be able to filter and criticise historical sources, be it in written or oral forms, before he writes

It is thus fathomable that Ibn Khaldun's methodology of thought on social change was also based on philosophy, which was the basis of state and historical research. He made an understanding of social change from historical aspects by understanding history and how to make it a lesson and guidance. Later he created and introduced basic concepts such as 'umrān, badawa, hädarah and 'așabiyyah which were explained, fitting to his extensive knowledge.

Nevertheless, in discussing the issue of social change, Ibn Khaldun denied the logical and metaphysical philosophy of Aristotle. Logic according to Ibn Khaldun is a science that maintains thought from making mistakes in comprehending unknown issues based on known and understood things (4). Ibn Khaldūn was a modestly conservative thinker in assessing the social change that took place during his time. He rejected all previous investigations and classified them as incomplete and inadequate. It was assumed that he likely based his own methodology on Ibn Rusyd's philosophy as the basis for the construction of historical philosophy. The philosophy of Ibn Rushd was based on the philosophical purpose itself which is to study all that exists and contemplate it as proof of the Creator.

However Ibn Khaldun used philosophical methodology to analyse the phenomenon of history and society, specifically on the issue of social change. He adamantly rejected metaphysical discussions using philosophical methodology (4). This is based on his definition of referring to metaphysics as a science beyond the physical world or knowledge of divinity. The ability of man who is only able to acquire knowledge using senses alone shows his own limitations. Therefore something beyond the boundaries of man will be impossible for them to be deeply debated.

Although the events of his time were associated with God as contained in his writing, he also viewed human beings should not use metaphysical approaches in scientific researches. He noted that social change should be interpreted based on scientifically defined facts (5). The metaphysical approach on the other hand must be applied in the concept of destiny, where social change takes place with the will of God as Khaliq or creator.

The next approach used by Ibn Khaldun in studying social change is a fairly scientific approach; the inquiry approach. This is evident when he would use a 'why' question each time the issue of social change was expressed in his writing (4). The 'why' question is answered with the beginning of the verse 'why it happens' or 'this happens because'. Such questions and answers form an experimental approach to sociology.
In education, the inquiry approach begins with questions, problems or scenarios. This approach is not merely to present strong facts or to illustrate knowledge alone but to begin with questions or queries as an introduction to deeper discussion. Since Ibn Khaldun also had an an extensive knowledge on education, he used an inquiry approach to strengthen his writing on social change. The inquiry approach is a pedagogical strategy where authors and readers study scientific events with the approach used by scientists. The process of discovering and researching issues, collecting data initiated by question or queries will be the trigger to a conclusion that can solve a problem that arises.

The use of an inquiry approach in writing the issue of social change involving factual variations such as events, concepts and generalizations was a precise choice made by Ibn Khaldun. Questions or the queries triggered curiosity among readers that they will seek knowledge and understanding on questions to fulfill the desire to further understand the reading. This approach was used by Ibn Khaldun in discussing such social changes as quoted in his book, which was in the form of question;

The interpretation and real meaning of the word "taste" according to the technical terminology of literary critics. An explanation of why Arabicized non-Arabs as a rule do not have it (6).

Detailed explanation on the dual meaning (mutasyabih) in the Qur'an and the al-sunnah and its causes are the forms of thought among ahl al-sunnah and ahl al-bidah.

Examples of answers to questions raised using the inquiry method; This is why we find that most non-Arab scholars in their research and classes do not copy comments (directly) from books but read them aloud (6).

This is why the common people say that, with the decrease of its civilization, the sustenance of a country disappears (6).

Furthermore, when studying an element of social change, he practiced a criticism approach as he was known to be a critical historian and studies something based on observation and sources of information (4). This was evident in his writing when Ibn Khaldun criticised the writings of historians who blatantly copied the sources of writing from previous historians without analysing the truth of the facts contained in the writing.

Ibn Khaldun listed the causes of mistakes made by historians in discussing social changes using the following characteristics; biased views, overconfidence, believing the truth recklessly, incapability of placing events in their true context, desire to be likeble to the superiors, sensationalising facts, and ultimately, ignorance or lack of knowledge in managing the transformation of human society. Hence, a new critical approach in studying history reached its peak in the fourteenth century through Ibn Khaldun's work.

At every stage of producing their work, historians must use their critical thinking skills and evaluate them objectively so that they can precisely draw from the sources about the past. They should check for biases and whether or not the sources are complete. At the same time, they should also be attentive of bias towards their own people or practising favouritism. Ultimately, it is impossible for a historian to be truly objective because he would not be able to neglect his moral values. Furthermore, the questions and assumptions he used to study the past did not reflect his time. This is because every age or era will find new questions and approaches for historical research; hence the final history of any topic is impossible to write.

However, the process that follows the selection is the assessment and interpretation followed by synthesis to the narrative should be done within a systematic framework. Resources are assessed by looking at its reasonableness and consistency (internal criticism) and comparing them with other evidences on the same topic (external criticism). This standard was the essence of the critical method established initially by Ibn Khaldun and in the 19th century it was compiled by a great historian from Germany, Leopold von Ranke.

Ibn Khaldun also uses a realistic approach in discussing issues on social change (4). This is what distinguishes himself from his fellow scholars in assessing social change in a realistic frame of reference. Ibn Khaldun considered idealism and realism to be of 
equal importance. In understanding history, Ibn Khaldun's thinking tends to be realistic. It also means he was a relativistic, temporalistic, and a materialistic person. However it must be understood that his primary reason for thought is religious knowledge. Therefore, it can be said that the realistic approach held by Ibn Khaldun is still within the bounds of religion.

With this realistic reference framework, Ibn Khaldun discussed the conflicts in the early history of Islam such as the conflict between Ali and Muawiyah. Scientifically, Ibn Khaldun analysed historical events from the aspect of 'asabiyyah strength that both had as a condition for strengthening their respective leadership. Based on the analysis, Ibn Khaldun opined that Muawiyah has a stronger 'asabiyyah spirit compared to Ali. At the same time the spirit of 'așabiyyah among Ali's followers was diminishing, which will affect Ali's leadership. In this situation, the leadership will be replaced with a stronger leader. This also means that anyone who has a strong sense of 'asabiyyah in their leadership will have the opportunity to replace Ali at that time.

His realistic approach led to the view of the need for differentiation between religious affairs and the world (4). Ibn Khaldun thinks that the prophet Muhammad (pbuh) was sent with the aim of teaching religion and managing the world. Ibn Khaldun clearly distinguished between religious affairs and worldly affairs. Everything that is done or spoken by the Prophet in relation to the worldly affairs needs to be placed in a temporary and relative context. Unlike religious affairs, worldly affairs had to be placed on the boundaries of the space and time in which the event takes place.

Taking inspiration from al-Mas'udi, Ibn Khaldun believed that an individual needs to balance his worldly life, between the influence of religion and race, as well as the influence of customary habits and changing beliefs. As he studied the events that had taken place throughout his life, he made a careful observation of the reality of his own community, or during a stopover location of anything he had came across. The information gathered from its analysis not only helped him in writing the implicit part of history, but also laid the foundation for the development of new civilisation knowledge.

The formulated methodology by Ibn Khaldun reflects logical, rational and objective thoughts when dealing with historical facts that discussed issues on social change (4). He stated in Muqaddimah that he assesses historiography using a rational analysis approach. For example, he neglected the writing of al-Mas'udi about the number of Moses's army without practicing the facts practically. He writes;

For example, al-Mas'udi and many other historians report that Moses counted the army of the Israelites in the desert. $33 \mathrm{He}$ had all those able to carry arms, especially those twenty years and older, pass muster. There turned out to be 600,000 or more. In this connection, (al-Mas'udi) forgets to take into consideration whether Egypt and Syria could possibly have held such a number of soldiers. Every realm may have as large a militia as it can hold and support, but no more (4).

This is because according to him, logically the number of such troops will make it difficult for the movement or cause difficulty in planning a strategy of warfare. Moreover, the strength of a government depends on the size of the administrative region. At that time, the size of the Persian government administration was greater than that of the Israelites.

He further compares the fact by stating;

Yet, the Persian army did not attain such a number or even approach it. The greatest concentration of Persian troops, at alQadisiyah, amounted to 120,000 men, all of whom had their retainersv (4).

According to him, if the Israelites had reached the sum of troops as what al-Mas'udi claimed, it means that the territory of the Israelites was equivalent to their military strength. Hence, the approach used by Ibn Khaldun is not only normative but empiricalpositive. According to him;

If this is so, the normative method for distinguishing right from wrong in historical information on the grounds of (inherent) pos- sibility or absurdity, is to investigate human social organization, which is identical with civilization (4).

The above quote explains that the normative approach used by Ibn Khaldun in explaining the issue of social change will help to differentiate between genuine and false facts. Therefore, in the perspective of any social changes that occur, the society will be more holistic and logical, as well as assisting in planning appropriate actions in dealing with the social changes that take place. The description in his writing suggests that it is not merely showing explicit facts but educating historians to see the implicit facts. This is one of Ibn Khaldun's greatest contributions to the formation of modern social science and history.

In the same example, researchers found that Ibn Khaldun applied the comparison approaches. Furthermore, according to him, the comparison approach enables the history of social change to emerge in a realistic perspective. He even suggested comparisons of historical writing should be made at a universal historical comparative level so that the application of this approach would purify social change in historical writing overall. He concluded by suggesting that comparative methods were extended to the universal human history. This can be the means of reducing racial, political and national prejudice among historians, in order to enable an overview of the true history of social change.

According to Baali and Wardi (7), in view of social phenomena, Ibn Khaldun played a role of an external observer and evaluated objectively and highlighted the value system standing behind him. In this case, none of the political analysts and historians could match Ibn Khaldun in comprehending the values inherent by the diversity of systems in society. For instance, he did not just explained what he sees in his journey but rather he attempted to dive into the surface to discover the hidden facts and the profound picture of his observations of society. This approach is known as the inductive approach (4).

In depth, it is understood that the method of inductive data processing is a method of data analysis through a pattern of thinking. This approach was done by Ibn Khaldun through the search of specific evidences, enabling him to produce general conclusions. It can also be easily understood that inductive is the conclusions made from general observations of specific. Ibn Khaldun's inductive research approach aimed at creating universal generalisation rather than specific facts.

This is because according to Ibn Khaldun, research and monitoring are important basis to explain the facts in the social realities that occur in history. It is a research perspective that requires careful and objective observation as well as measurement, coupled with careful and accurate data analysis to produce scientific findings on social change. In other words, according to Ibn Khaldun, this approach begins from the research of specific facts and events, along with generalisations to a general conclusion. This is specific in analysing social changes involving historical data; observations of facts require research on historical writing on the past.

This process will explain and give an overview of the social reality that took place during the time of Ibn Khaldun through the accumulation of relevant facts and events. Inductive approaches started with a collection of specific data, data analysis and ended with general conclusions. An inductive approach applied by Ibn Khaldun is mapped out based on Figure 2.1 below.

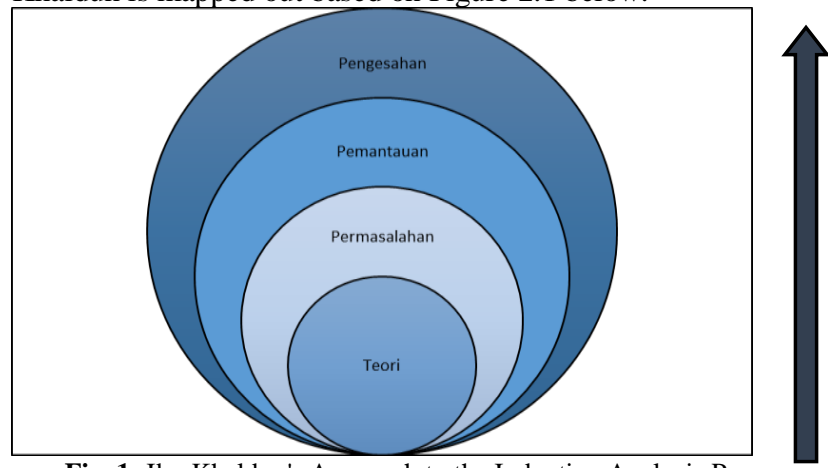

Fig. 1: Ibn Khaldun's Approach to the Inductive Analysis Process 
The method of deductive data processing on the other hand analyse data through thinking patterns and seeking general evidence to allow specific conclusions to the subjects. In other words, deductive can be understood as conclusions made from specific observations (8).

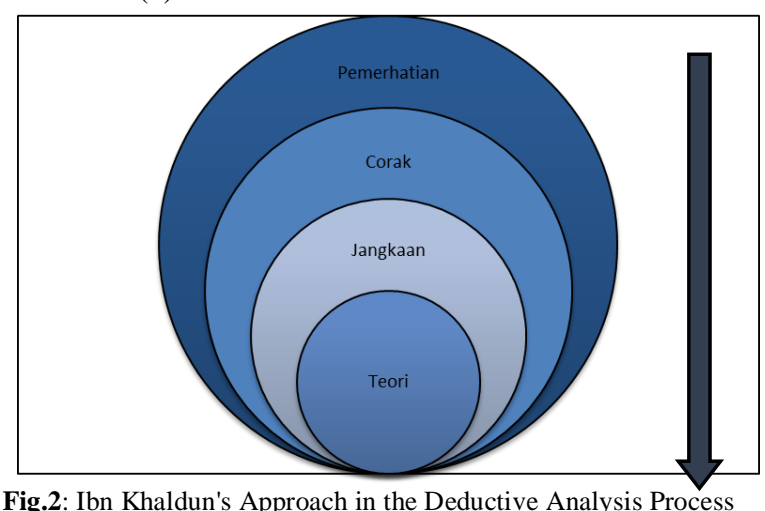

The deductive investigation strategy is a procedure based on a general event, whose truth is known or believed, and ends with a more specific conclusion or new knowledge. This analysis method started with the formation of theory, hypothesis or expectation and operational definition related to social change. Ibn Khaldun controls the whole concept and theory of social change and used that science to conduct research on social change and translate it in his writing.

Based on the general data derived from Ibn Khaldun's writing, he examined and analysed using the basis of the social change knowledge, where he manage to produce a conclusion about specific social change. Consequently, the use of deductive approaches requires a mastery of concepts and the theory of social change that becomes the key word for understanding a form of social change that applies at every level of society in history, as well as in the current and future studies.

Ibn Khaldun's last approach in discussing social change was through observation and participation (4). Ibn Khaldun was aware of the need for proper experience, observation and explicit resources before conducting an analysis. According to him, the writing of social change requires extensive diversity of resources and knowledge. Furthermore, it requires careful speculative thought. Both of these skills will assist in producing writings that were based on the truthful fact and avoiding inaccuries.

Ibn Khaldun understood that comprehensive knowledge of the past or the present is indispensable to produce great writings on the subject of social change. Knowledge of the past alone is insufficient to build a meaningful history. Hence, having the right knowledge of current developments will indirectly reflect the changes that have taken place in the past. The more knowledge they mastered, the more widespread their views of the past. A combination of past and present knowledge will result in a comprehensive analysis and a holistic view, where it is not based on a single perception or perspective. Therefore, mastering the knowledge is essential in processing credible resources so that the evaluation and writing will be credible as well.

In the meantime, Ibn Khaldun was able to combine the facts of knowledge and critical thinking (4). These two elements are significant and support each other to produce a holistic picture. His critical views were related to analytical methodology, while knowledge relates to the fact of the necessary information or conclusions from a particular context of events and phenomena. Critical views and contextual knowledge complement each other and are needed in the process of analysing information. Critical views will help in seeing hidden truths. However, critical views will not be trusted unless combined with constitutional knowledge, thus proving the truth.

Ibn Khaldun also recognised the need for proper experience, observation and resources before providing analysis. According to him, history writing requires a wealth of resources and knowledge, as well as good and precise speculative thinking. These two qualities will lead the analyst to the truth and preserve the errors.

His unique methodology when writing leaves space for more thorough assessment, as to what approaches were used in discussing social change issues. Even in his writings, Ibn Khaldun touched on his career path, showing us the significance of every social change that he himself experienced. The storytelling methodology shows that Ibn Khaldun was convinced of the value of his contribution to the formation of historical ideas in social change.

From the presentation aspect of Ibn Khaldun, he used a thematic writing approach (4). Writing using a thematic approach was

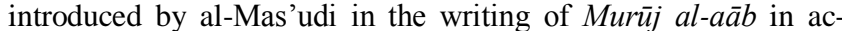
cordance with the order of the nation, the king and the people. This approach was then applied by Ibn Khaldun in the writing of social change in Muqaddimah Ibn Khaldun. The first chapter in his book was categorized under human development, which requires grouping, geography, and the impact of geographical change on the psychology of society, and the physical affects and activities of its civilization. This chapter represents the entire background to his writing in Muqaddimah Ibn Khaldun.

In the second chapter under the heading of the badawi society, he presented the method of addressing social change for human society. The discussion touches from the beginning of the badawi society to the extent of achieving civilisation. He also presented some valuable and profound views on the development of the history of the badawi society, such as the faster development of rural areas compared to the city, making rural areas as basis of development and township, local villagers who are more benevolent than the city dwellers, and the villagers practised racial solidarity compared to urban residents (9).

In the third chapter, Ibn Khaldun identified the journey of human society up to the formation of the state (4). When all the conditions and needs are fulfilled by a society, a nation will be born. The third chapter also deals with state issues, its age, harmful businesses run by governments and taxation. This can lead to tyranny, which is a signal to the destruction of development.

The fourth chapter is a continuation of the discussion in the third chapter which focuses on state matters and the role of the city as a center of civilisation, the relationship between the city and the nation, and discussing historical and legal situations that shape the existence of cities, its growth, recession and decline. This fourth chapter clearly demonstrates Ibn Khaldun's intellect with deep analysis and conclusions (10).

Meanwhile, his discussion shifted to economic issues in chapter five. He discusses income and employment issues. Also discussed were price, supply, demand, relationship between power and employment. It is more remarkable when he discussed on the issues of sustenance and employment as the value of human effort, possessing wealth due to one's high rank, happiness and occupations that are conquered by bootlickers .On the contrary, careers in religious affairs, kadi, mufti, teachers and so on do not bring wealth (9).

The fifth chapter also deals with agricultural, business, importexport, monopoly, inflation and handicraft activities. While the last chapter; the sixth chapter, Ibn Khaldun focused more on the topics of his knowledge and teachings. In fact, there is much discussion about the epistemology of knowledge, pedagogy, teaching as a career and the development of knowledge as a sign of high achievement of civilisation. He also discusses the scholars as those who distance themselves from the political field and many were non-Arab.

Furthermore, the approach of Ibn Khaldun in discussing social change was not spared from Islamic approaches as the basis of thought. Muqaddimah Ibn Khaldun, the manifestation of Ibn Khaldun's thoughts was inspired by the Qur'an as the primary and first source of Islamic teachings. This is confirmed by Muhammad Iqbal that the whole spirit of Muqaddimah Ibn Khaldun is the inspiration derived from the Qur'an (11). This is evident in the writing of Muqaddimah Ibn Khaldun containing Qur'anic verses and hadith. Whenever Ibn Khaldun presented an idea, he would confirm it with the Qur'anic verses or hadith and at the end of his 
writing he did not forget to praise or lay the last claim to Allah the Almighty as quoted below;

"And Allah gives His sovereignty to whom He wills. And Allah is all-Encompassing [in favor] and Knowing." (Al-Quran, 2:247) (4) .

\section{Conclusion}

The originality of Ibn Khaldun's thoughts lies in his rational personality, unaffected by the social change that took place at that time even though he himself was involved in the social change that took place. Both Muslim and Western scholars appreciate Ibn Khaldun's reasoning and methodology for attempting to explain history, society and religion with logic. Ibn Khaldun attempted to achieve an objective historical sociological understanding so that future civilisation can recognise the history of human society on the ever-changing social issues of life. This is because management of social change is an important agenda in the writing of Ibn Khaldun (12). Based on such important considerations, he applied a diversity of methodologies to facilitate the understanding of readers on social change and able to guide them to act wisely.

\section{References}

[1] Khaldun I. Abd al-Raḥman bin Muhammad bin Muhammad. Dīwān al-Mubtadā'wa al-Khabar fī Tārīkh al-'Arab wa al-Barbar wa 'Āṣarahum min Dhawī al-Sha'n al-Akbar, ed. Khalil Shahadah Beirut: Dār al-Fikr. 1988.

[2] Von Wright GH. Explanation and understanding: Cornell University Press; 2004.

[3] Rabī` MM. The political theory of Ibn Khaldūn: Brill; 1967.

[4] Khaldūn I. The Muqaddimah: an introduction to history; in three volumes. 1: Princeton University Press; 1969

[5] Faghirzadeh S. Sosiologi sosiologi: ITBM; 2004.

[6] Khaldūn I. al-Muqaddimah1980.

[7] Baali F, Wardi A, Mansuruddin, Thoha A. Ibn Khaldun \& pola pemikiran Islam: Pustaka Firdaus; 1989.

[8] Abd MN. Ghafar.(1999). Penyelidikan pendidikan Skudai: Penerbit Universiti Teknologi Malaysia.

[9] Khalil E. The Roadblock of Culturalist Economics: Economic Change á la Douglass North. 2006.

[10] Majid MKHA. Sosiologi Islam: Suatu Pengenalan. Jurnal Usuluddin. 1996;3:103-14.

[11] Iqbal M. The reconstruction of religious thought in Islam: Stanford University Press; 2013

[12] Halim H, Yusoff K. Analisis Kejatuhan Volga Bulgaria 1258 M. 2014. 